\title{
Adsorptive endocytosis and membrane recycling by cultured primary bovine brain microvessel endothelial cell monolayers
}

\author{
THOMAS J. RAUB* \\ Drug Delivery Systems Research, 7271-209-623, The Upjohn Company, 301 Henrietta St, Kalamazoo, MI 49001, USA
}

and KENNETH L. AUDUS

Department of Pharmaceutical Chemistry, University of Kansas, Lawrence, KS 66045, USA

* Author for correspondence

\section{Summary}

The dynamics of membrane recycling were examined in primary cultures of brain microvessel endothelial cells (BMECs). Because the BMEC surface was dominated by galactosylated glycoconjugates, ricin ag. glutinin (RCAI) was used as a tracer to follow the endocytosis and recycling of RCAI binding sites. These binding sites accounted for $75 \%$ of the iodinatable or most externally disposed plasma membrane proteins. Because greater than $90 \%$ of the RCAI that had bound to BMECs was removed by a brief, nontoxic treatment with galactose, the amounts and kinetics for internalization and efflux of $\left[{ }^{125}\right.$ I] RCAI were measured. Both endocytosis and efflux were energy dependent. By using pseudo-first-order kinetics, the $t_{1}$ values for RCAI binding, internalization and efflux were 5, 18 and 13-14 min, respectively. By comparing efflux with and without galactose present, we found that $60 \%$ of the RCAI binding sites that had been internalized were returned to the cell surface and reinternalized. Quantifying the distribution of gold-RCAI following internalization showed kinetics consistent with that obtained using radiolabeled RCAI. Both horseradish peroxidase (HRP) and gold-conjugated RCAI that had bound BMEC at $4^{\circ} \mathrm{C}$

became localized within more caveolae within $2.5 \mathrm{~min}$ of warming to $37^{\circ} \mathrm{C}$ to permit endocytosis. With time, RCAI appeared within endosomes and tubules and vesicles of which some were located in the trans-Golgi network (TGN). The distribution of HRP-RCAI contrasted with that of free HRP, which was not routed to the TGN. The absence of RCAI conjugates in association with the basolateral membrane domain suggested the presence of functional tight junctions and maintenance of polarity throughout the duration of these experiments. These results showed that membrane recycling was more extensive and much slower than fluid-phase endocytosis in cultured BMECs. Moreover, we found that endocytosis of membrane by BMECs in culture was similar to that reported for brain endothelium in vivo in that a fraction of the cell surface membrane was routed to the TGN.

Key words: blood-brain barrier, brain, endocytosis, endothelial cell, microvessel, recycling, ricin agglutinin, trans-Golgi network.

\section{Introduction}

The capillary endothelium that contributes to the bloodbrain barrier (BBB) is emerging as a uniquely dynamic and metabolically active cell barrier that protects and at the same time communicates with the central nervous system. The ability of the microvessel endothelium to regulate the movement of blood-borne proteins by exclusion or by selective transport pathways is generating a vast interest in characterizing the brain microvessel endothelial cell (BMEC) with regard to plasma membrane composition and the cell's capacity to accumulate and/or transport macromolecules by endocytosis (Pardridge, 1988; Brightman, 1989). With the development of in vitro models that include isolated microvessel capillaries (Goldstein et al. 1984; Pardridge et al. 1985) and cultured BMECs (Bowman et al. 1983; Audus and Borchardt, 1986; Journal of Cell Science 97, 127-138 (1990)

Printed in Great Britain (C) The Company of Biologists Limited 1990
Audus and Borchardt, 1987), transport pathways are being studied at the cellular level.

Reese and Karnovsky (1967) first demonstrated by using horseradish peroxidase (HRP) that BMECs in situ had less fluid-phase pinocytic activity relative to endothelia from other capillaries and this attribute became an identifying hallmark. While characterizing the in vitro model for use in transport studies, we became interested in the kinetics of fluid-phase endocytosis and showed that cultured BMECs also exhibited a low capacity for solute accumulation (Guillot et al. 1990). During that study, it was apparent that these cells were quite active with regard to membrane traffic or retrieval and recycling of the apical or blood-side plasma membrane. Little is known about endocytosis and membrane traffic within BMECs. Broadwell et al. (1988) recently showed for the first time by using a lectin conjugate that BMECs in vivo possess an intricate 
endocytic membrane system that involves prelysosomal compartments including those associated with the transmost Golgi cisternae.

As an adjunct to our previous work on fluid-phase endocytosis and to examine further membrane rather than solute traffic following endocytosis, we employed the lectin, Ricin communis agglutinin I (RCAI), as a tracer of adsorptive endocytosis. Isolated from the castor bean, RCAI is a glycoprotein with a molecular weight of $120 \times 10^{3}$ that binds carbohydrates that contain $\beta$-D-galactosyl or $\beta$-D- $N$-acetylgalactosaminyl residues (Olsnes et al. 1974). Because RCAI binds reversibly to cell surface proteins and glycolipids, internalization and recycling of these lectin binding sites could be followed quantitatively and qualitatively by using radiolabeled and electron-dense conjugates of RCAI.

\section{Materials and methods}

\section{Cell isolation and culture}

Bovine BMECs were isolated from gray matter of the cerebral cortex as described previously (Audus and Borchardt, 1986) and stored frozen at $-135^{\circ} \mathrm{C}$ in $10 \%(\mathrm{v} / \mathrm{v})$ dimethylsulfoxide prior to use. For culture, cells were plated onto plastic that had been coated with $1.5 \mathrm{mg} \mathrm{ml}^{-1}\left(0.17 \mathrm{mg} \mathrm{cm}^{-2}\right)$ rat tail collagen (Biomedical Technologies, Inc., Stoughton, MA), subsequently crosslinked in a saturated $\mathrm{NH}_{4} \mathrm{OH}$ atmosphere for $5 \mathrm{~min}$ and air dried, and $25 \mu \mathrm{g} \mathrm{ml}^{-1}$ (4-5 $\mu \mathrm{g} \mathrm{cm}^{-2}$ ) human fibronectin (Boehringer-Mannheim Biochemicals, Indianapolis. IN) at a density of 50000 cells cm$^{-2}$ in culture medium (Guillot et al. 1990) containing $120 \mu \mathrm{g} \mathrm{m}^{-1}$ heparin (162 USP units $\mathrm{mg}^{-1}$; Sigma Chemical Co., St Louis, MO). Cultures were maintained in a humidified mixture of $95 \%$ air and $5 \% \mathrm{CO}_{2}$ at $37^{\circ} \mathrm{C}$ and the medium was replaced every other day. After the formation of confluent cell monolayers within 10-12 days, experiments were carried out as described below. The purity of these cultures has been demonstrated elsewhere (Audus and Borchardt, 1986; BaranczykKuzma et al. 1986; Baranczyk-Kuzma et al. 1989; Guillot et al. 1990).

Established cultures of bovine brain and adrenal microvessel endothelial cells (a gift to The Upjohn Company from Dr Gospodarowicz, University of California Medical Center, San Francisco) were maintained as described (Gospodarowicz et al. 1986). MadinDarby bovine kidney epithelial cells (ATCC CCL 22) were grown in modified McCoy's 5A medium containing $10 \%(\mathrm{v} / \mathrm{v})$ heatinactivated newborn calf serum.

\section{Iodination of RCAI}

Ricinus communis agglutinin (RCAI or $\mathrm{RCA}_{120}$ from Vector Laboratories, Inc., Burlingame, CA) at $0.5 \mathrm{mg} \mathrm{ml}^{-1}$ in $200 \mu \mathrm{l}$ phosphate-buffered saline, $\mathrm{pH} 7.4$ (PBS), containing $0.1 \mathrm{M}$ galactose was iodinated by addition of two Iodo-Beads ${ }^{\mathrm{TM}}$ (Pharmacia, Piscatawy, $\mathrm{NJ}$ ) and $1.0 \mathrm{mCi}$ of $\mathrm{Na}^{125} \mathrm{I}$ (carrier-free; Amersham Corp., Arlington Heights, IL). After $10 \mathrm{~min}$ at $4^{\circ} \mathrm{C}$, free ${ }^{125} \mathrm{I}$ was removed by gel filtration. Samples of the void volume were dialyzed against PBS prior to use. Under these conditions, specific activity of the lectin was $2-4 \mu \mathrm{Ci} \mu \mathrm{g}^{-1}$ protein.

\section{Binding of $\left[{ }^{125} I\right] R C A I$ to $B M E C$ monolayers}

Confluent cell monolayers in 24-well plates (approximately $6 \times 10^{5}$ to $7 \times 10^{5} \mathrm{cells} /$ well) were preincubated for $30 \mathrm{~min}$ at $37^{\circ} \mathrm{C}$ in serum-free medium (SFM) prior to each experiment to remove adsorbed serum proteins. After rinsing with ice-cold SFM, the cells were incubated for $20 \mathrm{~min}$ at $4^{\circ} \mathrm{C}$ in $0.5 \mathrm{ml} \mathrm{SFM}$ containing $0.1 \mathrm{mg} \mathrm{ml}^{-1}$ bovine serum albumin (SFM/BSA) and [ $\left.{ }^{125} \mathrm{I}\right] \mathrm{RCAl}$ $\left(0.6 \mu \mathrm{g} \mathrm{ml}^{-1}\right.$ or $\left.5 \mathrm{nM}\right)$ alone, or with increased concentrations of unlabeled RCAI to determine the saturation curve of binding. The labeling medium was decanted and counted by gamma spectrometry. After washing the cells twice with $1 \mathrm{ml}$ ice-cold PBS, the labeled cells were solubilized with $1 \mathrm{ml}$ of $2 \%(\mathrm{w} / \mathrm{v})$ sodium carbonate, $0.4 \%(\mathrm{w} / \mathrm{v})$ sodium hydroxide, $0.16 \%(\mathrm{w} / \mathrm{v})$ sodium tartrate and $1 \%(\mathrm{w} / \mathrm{v})$ sodium dodecyl sulfate (SDS) and total cellassociated radioactivity and total protein (Markwell et al. 1981) were measured.

Each experiment comprised three or four wells per data point and used two different iodinated preparations. All values were expressed as the amount of total radioactivity that was cellassociated after correction for nonspecifically cell-associated radioactivity or that which had bound in the presence of $0.1 \mathrm{M}$ galactose. Greater than $95 \%$ of the radioactivity was bound specifically.

\section{Internalization of $\left[{ }^{125} I\right] R C A I$}

Confluent monolayers were allowed to bind and internalize $\left.{ }^{125} \mathrm{I}\right] \mathrm{RCAI}(2.5 \mathrm{nM})$ for up to $4 \mathrm{~h}$ by continuous incubation in SFM/BSA at $37^{\circ} \mathrm{C}$. To distinguish binding from uptake, the labeling medium was decanted, the cells rinsed once with ice-cold PBS, and surface-associated radioactivity was removed quantitatively with two $2.5 \mathrm{~min}$ washes (1 ml each) of ice-cold PBS containing 0.1 or $0.05 \mathrm{M}$ galactose. The remaining cell-associated label, measured as described above, was considered intracellular.

Alternatively, cells that had bound $\left[{ }^{125} \mathrm{I}\right] \mathrm{RCAI}$ at $4^{\circ} \mathrm{C}$ for $20 \mathrm{~min}$ were rinsed well and warmed to $37^{\circ} \mathrm{C}$ in SFM/BSA to allow internalization to proceed. At selected time intervals, the medium was decanted, the cells rinsed with ice-cold PBS and the surfaceassociated $\left[{ }^{126} I\right] R C A I$ removed with galactose. The stripped cells then were solubilized to measure the fraction of bound [ $\left.{ }^{125} \mathrm{I}\right] \mathrm{RCAI}$ that had been endocytosed.

Degradation of the $\left[{ }^{125}\right]$ RCAI was assessed by determining the amount of radioactivity that was soluble in $10 \%(\mathrm{w} / \mathrm{v})$ trichloroacetic acid (TCA). To each sample was added $0.1 \mathrm{mg} \mathrm{m}^{-1} \mathrm{BSA}$ as a carrier. Alternatively, degradation was measured by the percentage of radioactivity that passed through a $10^{4} M_{\mathrm{r}}$ cutoff Centricon- $10^{\mathrm{TM}}$ filter (Amicon Corp., Danvers, MA).

The effects of exposure to RCAI on cell viability under the conditions described herein were examined. Confluent cultures were either pulse labeled with $0-50 \mu \mathrm{g} \mathrm{ml}^{-1}$ RCAI for $30 \mathrm{~min}$ at $4^{\circ} \mathrm{C}$, rinsed and incubated for $2 \mathrm{~h}$ at $37^{\circ} \mathrm{C}$, or incubated continuously with $0-50 \mu \mathrm{g} \mathrm{ml}^{-1} \mathrm{RCAI}$. After rinsing, the viability of cells in these cultures was determined by using fluorescein diacetate and ethidium bromide (Carson and Haudenschild, 1986).

\section{Recycling of accumulated $\left[{ }^{125} I\right] R C A I$}

Cells that had been allowed to accumulate $\left[{ }^{125}\right] \mathrm{RCAI}$ as described above were chilled and the surface-bound lectin removed with $0.1 \mathrm{~m}$ galactose. Washed cells were rewarmed to $37^{\circ} \mathrm{C}$ in SFM/ BSA with or without $0.05 \mathrm{M}$ galactose. Efflux was measured for up to $60 \mathrm{~min}$ by determining the amount of TCA-insoluble radioactivity that had returned to the cell surface. The cells were then solubilized to measure the amount of cell-associated radioactivity that was not recycled or released by galactose.

\section{Radiolabel incorporation into cellular proteins}

After incubating cell monolayers in SFM for $1 \mathrm{~h}$ at $37^{\circ} \mathrm{C}$ cell surface components of intact BMECs were labeled with ${ }^{125} \mathrm{I}$ by using lactoperoxidase according to Hubbard and Cohn (1975). Alternatively, BMECs grown in $100-\mathrm{mm}$ dishes were preincubated in minimum essential medium (MEM) without glutamine and glucose (Gibco Laboratories, Grand Island, NY), and after $30 \mathrm{~min}$ the medium was replaced with $5 \mathrm{ml}$ of glucose-free $\mathrm{MEM}$ containing $50 \mu \mathrm{Ci} \mathrm{ml}^{-1}$ D- $\left[1,6-{ }^{3} \mathrm{H}(N)\right]$ glucosamine hydrochloride (42.5 $\mathrm{Ci} \mathrm{mmol}^{-1}$; New England Nuclear, Boston, MA). After 3-5 h at $37^{\circ} \mathrm{C}$, an additional $5 \mathrm{ml}$ of complete culture medium were added and the incubation continued for $5-14 \mathrm{~h}$. The labeled cells were rinsed well, incubated for an additional hour and then lysed as described below.

\section{Affinity isolation of RCAI binding proteins}

Radiolabeled cells were rinsed with ice-cold PBS and incubated for $1 \mathrm{~h}$ at $4^{\circ} \mathrm{C}$ in TBS $(0.02 \mathrm{M}$ Tris-HCl, pH $8,0.15 \mathrm{M} \mathrm{NaCl})$ containing $1 \%(\mathrm{w} / \mathrm{v})$ deoxycholic acid (DOC), $0.001 \mathrm{M}$ ethylenediaminetetraacetic acid (EDTA), $0.001 \mathrm{M}$ phenylmethylsulfonyl fluoride (PMSF), $1 \mu \mathrm{g} \mathrm{ml}{ }^{-1}$ leupeptin, 0.2 t.i.u. $\mathrm{ml}^{-1}$ aprotinin and 
$0.02 \%(\mathrm{w} / \mathrm{v})$ sodium azide. After the lysate was clarified by centrifugation at $11000 \mathrm{~g}$ for $5 \mathrm{~min}$, TCA-insoluble radioactivity was determined by soaking lysate-spotted glass fibre filters in $10 \%(\mathrm{w} / \mathrm{v})$ TCA containing $0.05 \mathrm{~m}$ glucosamine (Hubbard and Cohn, 1975).

The lysates were passed through a column of $5 \mathrm{ml}$ of agarosebound $\mathrm{RCA}_{120}\left(\mathbf{4} \mathrm{mg} \mathrm{ml}^{-1}\right.$; Vector) equilibrated in TBS containing $0.5 \%(w / v)$ DOC. After rinsing with 20 column volumes of TBS, bound material was eluted with 2 column volumes of TBS containing $0.5 \mathrm{M}$ galactose. Both bound and unbound fractions were dialyzed against distilled water containing $1 \mathrm{~mm}$ PMSF and sodium azide and lyophilized prior to analysis by gel electrophoresis.

\section{Gel electrophoresis}

The RCAI-bound and -unbound fractions of radiolabeled cell lysates were reconstituted and boiled in reducing buffer before subjecting them to one-dimensional SDS-polyacrylamide gel electrophoresis (1D-SDS-PAGE) according to Laemmli (1970). Gels were fixed, Coomassie Blue stained, treated with Enlightning ${ }^{\text {TM }}$ (New England Nuclear) $\left(\left[{ }^{3} \mathrm{H}\right]\right.$ glucosamine only) and dried prior to exposure to XAR-5 X-ray film (Eastman Kodak Co., Rachester, NY) at $-70^{\circ} \mathrm{C}\left(\left[^{3} \mathrm{H}\right\rceil g l u c o s a m i n e\right)$ or at $25^{\circ} \mathrm{C}$ with a Cronex Quanta II ${ }^{\mathrm{TM}}$ (E.I. du Pont Nemours \& Co., Wilmington, DE) intensifying ecreen $\left({ }^{125} \mathrm{I}\right)$.

Autoradiograms of the bound proteins were analyzed by using the Visage 110 System (BioImage, Ann Arbor, MI). Each lane was scanned using a Kodak $1024 \times 1024$ two-dimensional array camera and image analysis was carried out using Visage System software.

\section{Fluorescence microscopy}

Bovine BMECs grown to confluence in plastic 2-chamber Lab Tek $^{\text {TM }}$ Chamber/Slides (Miles Scientific, Inc., Naperville, IL) were treated as above and incubated for $30 \mathrm{~min}$ at $4^{\circ} \mathrm{C}$ in PBS with $50 \mu \mathrm{g} \mathrm{ml}^{-1}$ fluorescein isothiocyanate (FITC)-lectin (Vector). Control cells were labeled in the presence of $0.2 \mathrm{M}$ of the haptene sugar (Sigma Cemical Co., St Louis, MO). In experiments where lectin internalization was observed, cells were incubated with $25 \mathrm{ug} \mathrm{ml}^{-1}$ FITC-lectin in serum-free medium at 37,18 and $4^{\circ} \mathrm{C}$ with or without $0.1 \mathrm{M}$ hapten sugar. Labeled cells were fixed at $4^{\circ} \mathrm{C}$ for 30 min in $4 \%(\mathrm{w} / \mathrm{v})$ paraformaldehyde in PBS, mounted in $80 \%(\mathrm{v} / \mathrm{v})$ glycerol in PBS, and viewed with epifluorescence.

\section{Internalization of RCAI conjugates and HRP}

Confluent BMECs monolayers in chamber/slides were chilled on ice, thoroughly rinsed with $\mathrm{PBS}$, and incubated with $25 \mu \mathrm{g} \mathrm{ml}^{-1}$ HRP-RCAI (Sigma) or $5.7 \mu \mathrm{g} \mathrm{ml}^{-1}$ of gold $(10 \mathrm{~nm})-\mathrm{RCAI}$ (E-Y Laboratories, San Mateo, CA) for $30 \mathrm{~min}$ at $4^{\circ} \mathrm{C}$. Control cells were incubated either with unlabeled RCAI or with conjugate in the presence of $0.1 \mathrm{M}$ galactose. Cells were washed free of unbound label and either processed immediately for electron microscopy or warmed to $37^{\circ} \mathrm{C}$ in SFM for selected time intervals prior to processing. For HRP accumulation, cell monolayers were incubated in complete medium containing $1 \mathrm{mg} \mathrm{m}^{-1}$ HRP (type I; Sigma). In the uptake experiments, control cells were maintained at $4^{\circ} \mathrm{C}$ to prevent internalization.

\section{Electron microscopy}

Labeled cell monolayers were washed with ice-cold PBS and fixed for $30 \mathrm{~min}$ with $2.5 \%(\mathrm{v} / \mathrm{v})$ glutaraldehyde (Polysciences, Inc., Warrington, PA) in 0.1 m sodium cacodylate buffer, $\mathrm{pH}$ 7.4. Cells labeled with HRP were treated as described previously (Raub et al. $1990 \mathrm{a}$ ). Washed cell monolayers were post-fixed for $1 \mathrm{~h}$ in $2 \%$ $(\mathrm{w} / \mathrm{v}) \mathrm{OsO}_{4}$ with or without $1 \%(\mathrm{w} / \mathrm{v})$ potassium ferricyanide in $0.1 \mathrm{~m}$ sodium cacodylate, $\mathrm{pH} 7.4$, dehydrated through a graded series of ethanol, and embedded in dish in Poly/Bed ${ }^{\mathrm{TM}} 812$ (Polysciences) (Luft, 1961). Sections of 60-80 nm thickness were mounted on $0.25 \%(\mathrm{w} / \mathrm{v})$ Formvar-coated grids, doubly poststained (Reynolds, 1963), and viewed by using a JEOL 1200EX electron microscope operated at $60 \mathrm{kV}$.

Binding and distribution of the gold-RCAI conjugate was quantified from micrographs by counting the number of gold particles that were associated with the apical plasma membrane, caveolae, intracytoplasmic vesicles, endosomes and the basolateral membrane. Particle densities were determined by expressing the number of particles per $\mu \mathrm{m}$ of membrane that was measured from micrographs at constant magnification $(\times 100000)$ by using Sigma-Scan ${ }^{\text {TM }}$ (Jandel Scientific, Corte Madera, CA).

\section{Results}

\section{Lectin binding to $B M E C s$ in vitro}

We began this study by surveying a number of lectins (Table 1) that recognize a wide variety of monosaccharides. Our intention was to identify a lectin that had the largest number of apparent binding sites on the BMEC surface for use as a general adsorptive tracer of plasma membrane (glycoprotein and glycolipid) traffic in these cells. Relative fluorescence intensities (Table 1) were judged by fluorescence microscopy following incubation of confluent BMEC monolayers with FITC-lectin. All of the lectins were used at a similar concentration $(0.42-0.45 \mu \mathrm{M})$ except for Ulex europaeus agglutinin I (UEAI) $(0.3 \mu \mathrm{m})$ and wheat germ agglutinin (WGA) $(1.4 \mu \mathrm{M})$. Since there was no correlation between the intensity of staining and the concentration of fluorescein used (calculated from the fluorescein/protein ratio of each lectin), which varied from 1.1 to $3.2 \mu \mathrm{M}$ fluorescein, we suggest that the relative intensities were due to the density of cell surface binding sites. All of the control cells that were labeled in the presence of $0.2 \mathrm{M}$ of the haptene sugar (Table 1) failed to bind lectin (results not shown). Both RCAI and soy bean agglutinin (SBA) bound with the greatest intensity and indicated that the cultured BMEC surface is rich in D-galactose and D- $N$-acetylgalactosamine residues. In contrast, the absence of either UEAI or Dolichos biforus aggutinin (DBA) binding suggested that RCAI and SBA recognized primarily the $\beta$ configuration.

All of the lectins that bound to BMECs at $4^{\circ} \mathrm{C}$ displayed a uniformly punctate distribution on the cell surface as viewed by fluorescence microscopy (results not shown). By using HRP-lectin conjugates and electron microscopy, the bound lectins were confined to the luminal or apical plasma membrane, which suggested that the conjugate was excluded by the tight junctions. The lectin conjugates also labeled caveolae (see Fig. 6, below).

Table 1. Relative fluorescence intensities of FITC-lectins that had bound to confluent (day 10) BMECs

\begin{tabular}{|c|c|c|}
\hline Agglutinin & Sugar specificity & $\begin{array}{l}\text { Relative } \\
\text { intensity }\end{array}$ \\
\hline Ulex europaeus I (UEAI) & $\alpha-L-F u c o s e$ & - \\
\hline Doluchas bifuras (DBA) & $\alpha$-D-GalNAc, $\alpha-\mathrm{D}-\mathrm{Gal}$ & - \\
\hline Concanavalin A (Con A) & $\begin{array}{l}\text { a-D-Man, } \alpha \text {-D-Glc, } \\
\alpha \text {-D-GlcNAc }\end{array}$ & + \\
\hline $\begin{array}{l}\text { Peanut (Arachus hypogaea) } \\
\text { (PNA) }\end{array}$ & $\beta$-D-Gal(1-3)-D-GalNAc & + \\
\hline Wheat germ (WGA) & $\beta$-D-GlcNAc, NA & ++ \\
\hline $\begin{array}{l}\text { Soy bean (Glycine max) } \\
\text { (SBA) }\end{array}$ & $\begin{array}{l}\alpha-\mathrm{D}-\mathrm{GalNAc}, \beta-\mathrm{D}-\mathrm{GalNAc}, \\
\beta-\mathrm{D}-\mathrm{Gal}\end{array}$ & +++ \\
\hline $\begin{array}{l}\text { Ricinus communis I } \\
\text { (RCAI) }\end{array}$ & $\beta$-D-Gal, $\beta$-D-GalNAc & +++ \\
\hline
\end{tabular}

Washed cell monolayers were incubated with $50 \mu \mathrm{g} \mathrm{ml}^{-1}$ FITC-lectin for $30 \mathrm{~min}$ at $4^{\circ} \mathrm{C}$, rinsed, fixed with $4 \%$ paraformaldehyde and viewed with epifluorescence microscopy. Relative intensity: $(-)$ none, $(+)$ weak, $(++)$ moderate, $(+++)$ strong.

Abbreviations: Gal, galactose; GalNAc, $N$-acetylgalactosamine; Glc glucose; GlcNAc, $N$-acetylglucosamine; Man, mannose; NA, neuraminic acid. 
Binding and release of $R C A I$ from cultured $B M E C s$

To establish the conditions at which subsequent internalization experiments were to be done, the kinetics of RCAI-BMEC interactions were examined. Both the association rate at $4^{\circ} \mathrm{C}$ and the dissociation rate at $37^{\circ} \mathrm{C}$ were determined and both were at steady-state after 20 min (results not shown). For dissociation, paraformaldehyde-fixed cells were used to measure kinetics at $37^{\circ} \mathrm{C}$ without accompanying endocytosis. Under these conditions, as much as $45 \%$ of the RCAI that had bound at $4{ }^{\circ} \mathrm{C}$ was lost into the medium within $30 \mathrm{~min}$. Using pseudofirst order kinetics (Owensby et al. 1989), the 'off' rate had a $t_{i}$ of $4 \mathrm{~min}$. The 'on' rate was determined to have a $t_{i}$ of $6 \mathrm{~min}$. For dissociation, a similar value was observed during internalization (see Fig. 4, below), suggesting that fixation did not alter the kinetics. In all cases, three quick rinses with $\mathrm{PBS}$ at $4^{\circ} \mathrm{C}$ were sufficient to remove all of the unbound lectin.

After incubation for $20 \mathrm{~min}$ at $4^{\circ} \mathrm{C}$, saturation was reached at $15 \mu \mathrm{g} \mathrm{ml}^{-1}$ (Fig. 1). By using $\left[{ }^{125} \mathrm{I}\right] \mathrm{RCAI}$ (5 nM) either with increasing concentrations of unlabeled RCAI or in the presence of $0.1 \mathrm{M}$ galactose, we found that 94-96\% of the binding was specific. Similar results were obtained using capillary endothelia derived from bovine adrenal (results not shown). The surface-bound RCAI was removed rapidly and quantitatively with $93( \pm 2) \%$ efficiency by using two, 5 -min rinses with $0.05-0.1 \mathrm{M}$ galactose at $4^{\circ} \mathrm{C}$. RCAI that had associated with BMECs at $37^{\circ} \mathrm{C}$ gradually became inaccessible for removal by galactose. This provided a way of distinguishing between RCAI at the cell surface and that which had been internalized by the cells.

\section{Identification of RCAI binding proteins on the BMEC surface}

Cell surface glycoproteins that bound RCAI were identified by using whole-cell radioiodination followed by lectin-affinity chromatography. Labeled proteins that had bound to immobilized RCAI were eluted with galactose and analyzed by 1D SDS-PAGE and autoradiography. Of the proteins that were iodinated in intact cells, $76 \%$ of the TCA-insoluble radioactivity bound RCAI (Fig. 2). Following incorporation of $\left[{ }^{3} \mathrm{H}\right]$ glucosamine, $59 \%$ of the TCAinsoluble radioactivity bound RCAI (results not shown). In contrast, only $3.5 \%$ and $4.2 \%$ of the TCA-insoluble $\left[{ }^{35} \mathrm{~S}\right]$ methionine- and $\left[{ }^{3} \mathrm{H}\right] l$ eucine-labeled radioactivity bound RCAI (results not shown). In all cases, the same major RCAI-binding proteins were observed at 180-185, $155,135-140$, and $115-120 \times 10^{3} M_{\mathrm{r}}$ (Fig. 2).

The relative amounts of these glycoproteins, especially those greater than $120 \times 10^{3} M_{\mathrm{r}}$, increased with age in culture without an increase in cell number. A significant change in composition was not observed (Fig. 2). We also compared the expression of four of the RCAI binding proteins that had been labeled with $\left[{ }^{3} \mathrm{H}\right]$ glucosamine between primary BMECs (day 14 of culture), few (pass 4) and many (pass 12) passaged primary BMECs, passaged bovine adrenal endothelia, and bovine kidney epithelia (MDBK). A $185 \times 10^{3} M_{\mathrm{r}}$ glycoprotein was lost in the many passaged BMECs and also was absent in MDBK. In contrast, a $165 \times 10^{3} M_{\mathrm{r}}$ glycoprotein that was absent in primary BMECs was found in few and many passaged BMECs and in MDBK (results not shown).

\section{Endocytosis of RCAI by BMECs}

The kinetics of lectin-membrane internalization were studied by using both a continuous incubation at $37^{\circ} \mathrm{C}$

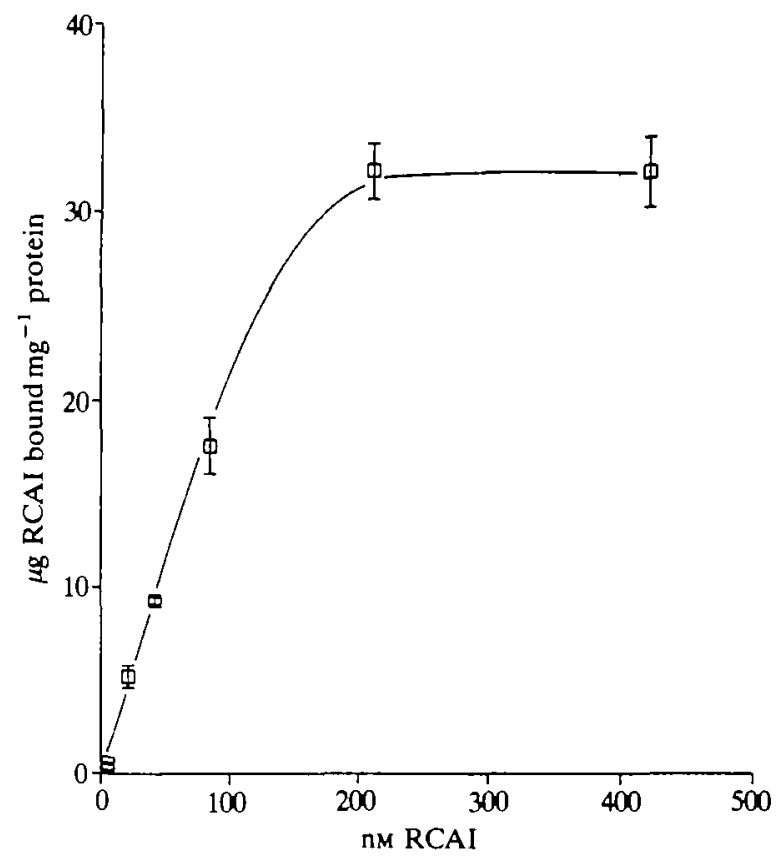

Fig. 1. Saturation curve of RCAI binding to confluent BMECs monolayers at $4^{\circ} \mathrm{C}$. Cells at day 10 in culture were incubated with $5 \mathrm{nM}\left[{ }^{125}\right.$ I]RCAI and increasing amounts of unlabeled RCAI for $20 \mathrm{~min}$ at $4^{\circ} \mathrm{C}$. After rinsing, the cells were solubilized and the amount of radioactivity that had bound was measured. Total cellular protein per well was determined as described in the text and was corrected for the amount contributed by the extracellular matrix used to coat the growth surface. The means and standard deviations from triplicate wells were corrected for the amount of RCAI that bound in the presence of $0.1 \mathrm{~m}$ galactose.

with $\left[{ }^{125} \mathrm{I}\right] \mathrm{RCAI}(2.5 \mathrm{nM})$ and a pulse-label at $4{ }^{\circ} \mathrm{C}$ followed by a 'chase' at $37^{\circ} \mathrm{C}$. The distribution of RCAI in continuously incubated cells was determined by using a galactose wash at $4^{\circ} \mathrm{C}$ to distinguish surface-bound RCAI from that which had been internalized (Fig. 3). Pseudo-first-order kinetics gave a $t_{1}$ of $5 \mathrm{~min}$ for the rate at which RCAI became cell surface associated. In comparison, the $t_{1}$ for RCAI accumulation into a galactose-resistant form was $18 \mathrm{~min}$. Both binding and subsequent intracellular accumulation gradually decreased to a steady-state rate with a $t_{1}$ of $78 \mathrm{~min}$. This decrease in the accumulation rate was not due either to depletion of the lectin or to a decrease in endocytic activity, since endocytosis of Lucifer Yellow remained unchanged following incubation with RCAI (results not shown). Furthermore, under these conditions RCAI was not toxic to the BMEC, since viability did not differ from untreated cultures.

During continuous incubation, RCAI binding and endocytosis were inhibited by the presence of $0.05 \mathrm{M}$ galactose in the serum-free medium. After $2 \mathrm{~h}$, only $5-6 \%$ of the RCAI was accumulated, most likely by fluid-phase endocytosis (Fig. 3). Furthermore, internalization was inhibited completely at $4{ }^{\circ} \mathrm{C}$ and was reduced by $65-75 \%$ in the presence of $50 \mathrm{~mm} 2$-deoxyglucose and $5 \mathrm{~mm}$ sodium azide (results not shown).

For pulse-chase experiments, cells were allowed to bind subsaturating concentrations of RCAI $(<5 \mathrm{nM}$ ) for $20 \mathrm{~min}$ at $4^{\circ} \mathrm{C}$, rinsed and warmed to $37^{\circ} \mathrm{C}$ in the absence of lectin to allow endocytosis to proceed (Fig. 4). Pseudo-first-order kinetics gave a $t_{l}$ of $14 \mathrm{~min}$ for the rate of internalization. 

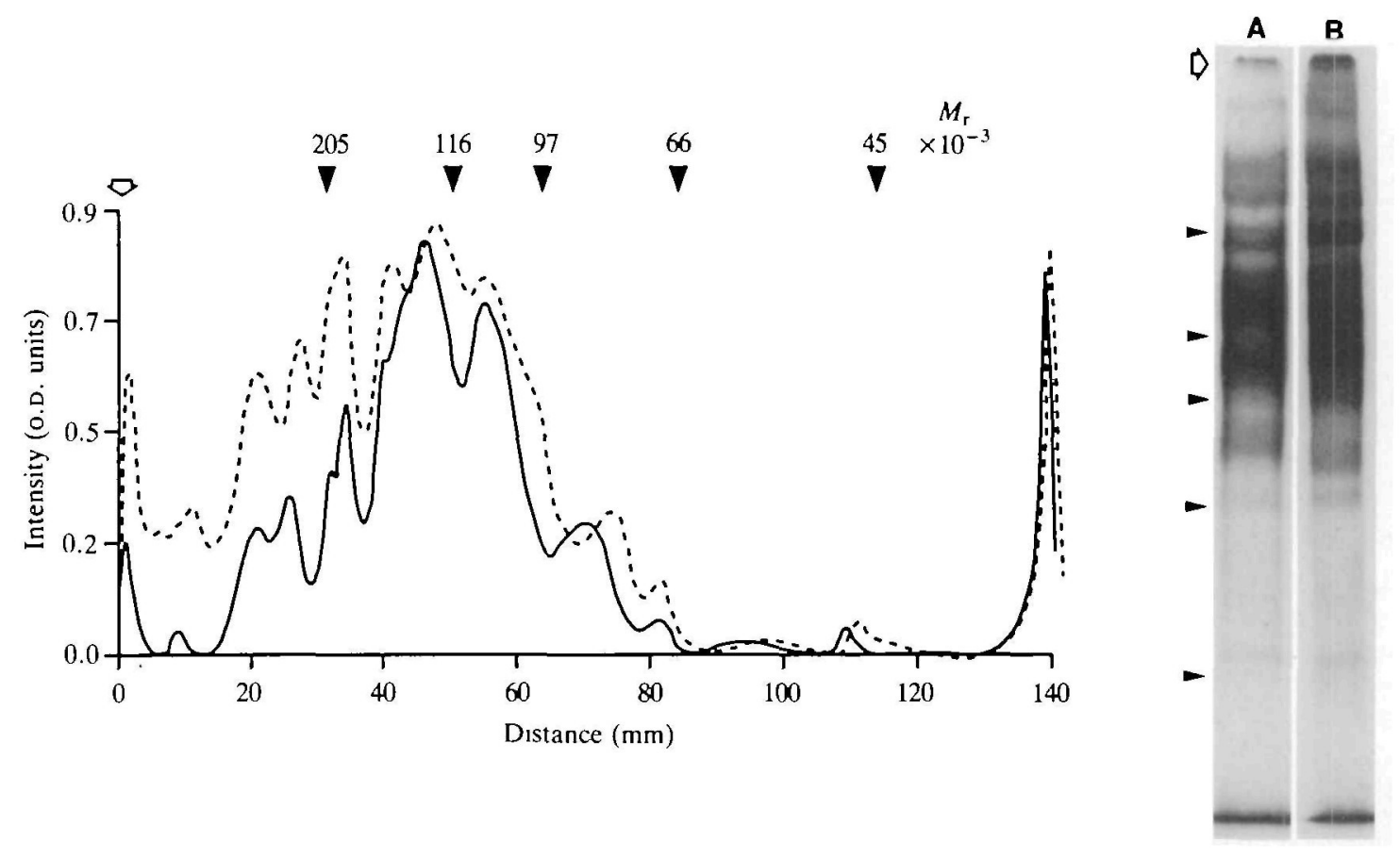

Fig. 2. Densitometric scan of RCAI binding proteins from BMECa that had been radiolabeled by lactoperoxidase-catalyzed iodination. Intact BMECs at day 8 (lane A and continuous line) and day 14 (lane B and broken line) in culture were labeled with ${ }^{125} \mathrm{I}$, detergent-solubilized and the lysate passed through a column of RCAI-agarose. Bound proteins were eluted with $0.5 \mathrm{M}$ galactose, dialyzed, lyophilized and $50000 \mathrm{cts} \mathrm{min}^{-1}$ (acid-insoluble) subjected to reducing 1D-SDS-PAGE followed by autoradiography. The autoradiograms (lanes A and B) were scanned from top (open arrow) to bottom by image analysis as described in Materials and methods and plotted versus molecular weight markers (arrowheads).

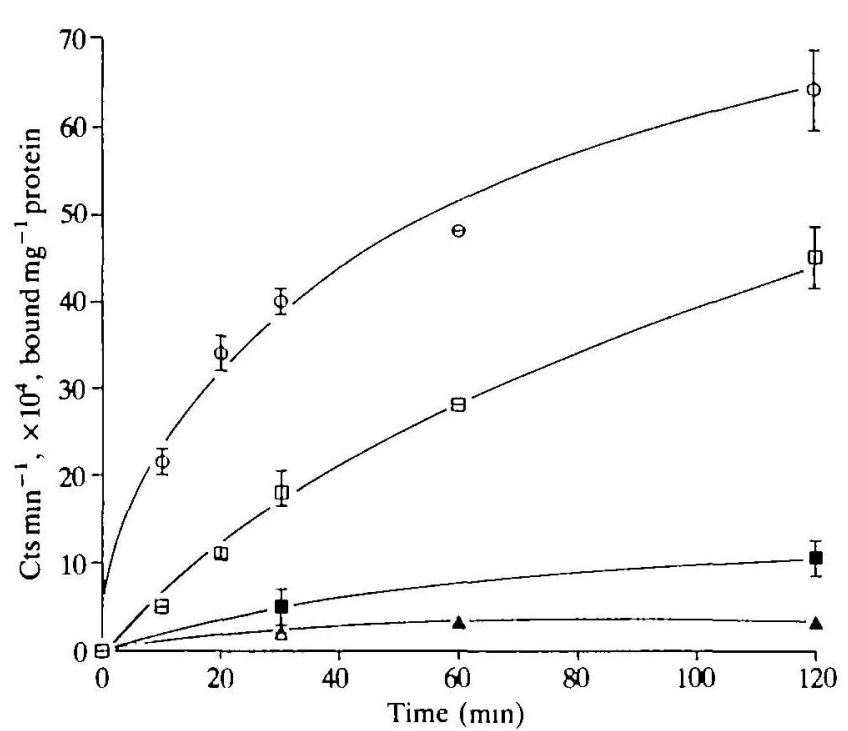

Fig. 3. Time course for binding and accumulation of RCAI by confluent BMEC monolayers during continuous exposure. Cells at day 12 in culture were incubated at $37^{\circ} \mathrm{C}(O, \square, \triangle)$ or $4^{\circ} \mathrm{C}(\mathbf{\square})$ in serum-free medium with $2.5 \mathrm{nM}\left[{ }^{125} \mathrm{I}\right] \mathrm{RCAI}$. At selected times, cells were rinsed in ice-cold PBS and the amounts of lectin that were intracellular $(\square, \square, \triangle)$ or at the cell surface $(O)$ were distinguished by using two, 5-min rinses with $0.1 \mathrm{M}$ galactose. Endocytosis of RCAI was inhibited at $4^{\circ} \mathrm{C}(\mathbf{C})$ and at $37^{\circ} \mathrm{C}$ in the presence of $0.05 \mathrm{M}$ galactose $(\triangle)$. The values represent the means and standard deviations from 3-6 sets of triplicate wells. All values were normalized to total cellular protein and were corrected for nonspecific binding in the presence of galactose.

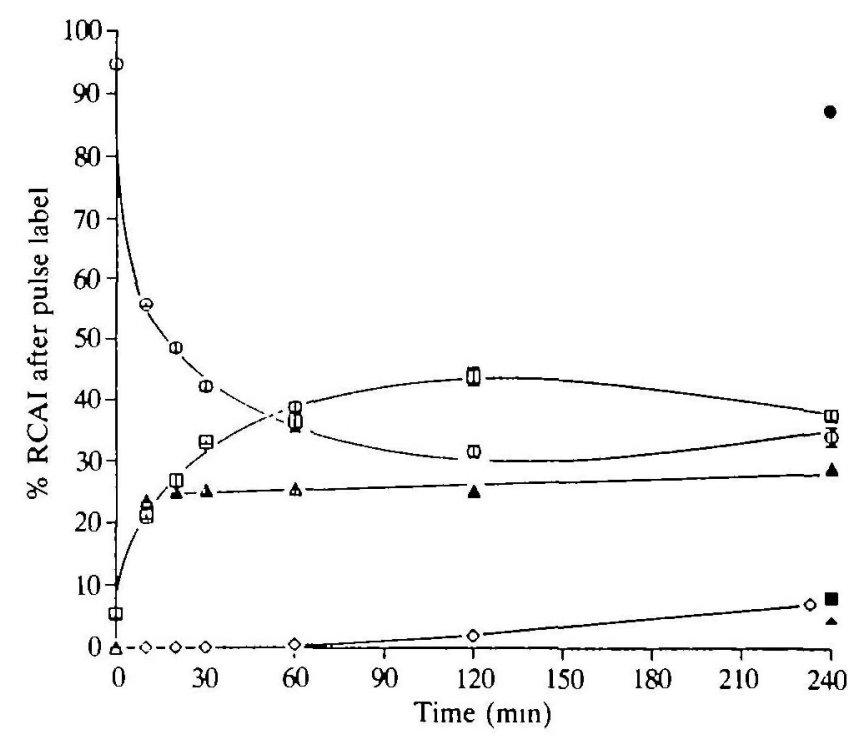

Fig. 4. Fate of RCAI that had bound to confluent BMEC monolayers after warming the labeled cells to $37^{\circ} \mathrm{C}$. Cells at day 12 in culture were allowed to bind $\left[{ }^{125} \mathrm{I}\right] \mathrm{RCAI}$ as described for Fig. 1, rinsed well, and warmed to $37^{\circ} \mathrm{C}$ in serum-free medium. At selected times, the amounts of RCAI that (1) appeared in the medium $(\triangle, \Delta) ;(2)$ were at the cell surface $(\mathrm{O}, 0)$, which was determined by removal with $0.1 \mathrm{M}$ galactose; and (3) were intracellular ( $\square, \mathbf{a})$, were measured as a fraction of the radioactivity that had been cell-associated. Control cells that were maintained at $4^{\circ} \mathrm{C}(\boldsymbol{\varphi}, \boldsymbol{\square}, \mathbf{\Lambda})$ did not accumulate RCAI. Only a small fraction of the bound RCAI was degraded gradually as shown by the appearance of radioactivity in the medium $(\diamond)$ that either passed through a $10^{4} M_{\mathrm{r}}$ cutoff filter or was soluble in $10 \%(\mathrm{w} / \mathrm{v})$ TCA. 
Within $1 \mathrm{~h}, 35-40 \%$ of the cell-associated radioactivity was at equilibrium with intracellular compartments. The rapid loss from the cell surface fraction was a sum of that portion internalized and that which dissociated prior to endocytosis.

Degradation of RCAI was measured by the amount of TCA-soluble radioactivity or the amount of radioactivity that passed through a $10 \times 10^{3} M_{\mathrm{r}}$ molecular weight cut-off filter. Degradation was temperature-dependent and was not detected until after $30 \mathrm{~min}$ at $37^{\circ} \mathrm{C}$ when low molecular weight radioactive fragments gradually began to appear. Less than $7 \%$ of the cell-associated RCAI was degraded during $4 \mathrm{~h}$ at $37^{\circ} \mathrm{C}$ (Fig. 4).

\section{The endocytic pathway}

To correlate our kinetic results using $\left[{ }^{125} \mathrm{I}\right] \mathrm{RCAI}$ with morphology, we used FITC-, HRP- and gold-conjugates of RCAI in parallel experiments and assumed that these conjugates behaved like the native lectin. Internalization was followed by fluorescence and electron microscopy after pulse labeling at $4^{\circ} \mathrm{C}$. We initially established that surface-bound FITC-RCAI became localized within compartments that were refractory to the galactose wash (Fig. 5). At $18^{\circ} \mathrm{C}$, a temperature that inhibits post-endosome events (Sandvig and Olsnes, 1979; Dunn et al. 1980), lectin was internalized, but the RCAI-containing vesicles were smaller in size and were more numerous (Fig. 5B) than those at $37^{\circ} \mathrm{C}$ (Fig. $5 \mathrm{C}$ ).

Both HRP- and gold-RCAI were used, since each has advantages in visualizing endocytic compartments. The HRP-conjugate by virtue of its amplified signal is visualized at low concentrations, although resolution of localization is less than for the gold conjugate. Moreover, the HRP-RCAI probe is more like native RCAI, since it is a soluble protein whereas the gold-RCAI probe is an insoluble particle that contains many RCAI molecules per particle. Despite this polyvalency, the gold probe can be used to quantify internalization. By comparing our results qualitatively and quantitatively, both probes behaved alike and similar to unconjugated RCAI.

Ricin agglutinin I conjugates that had bound to BMEC
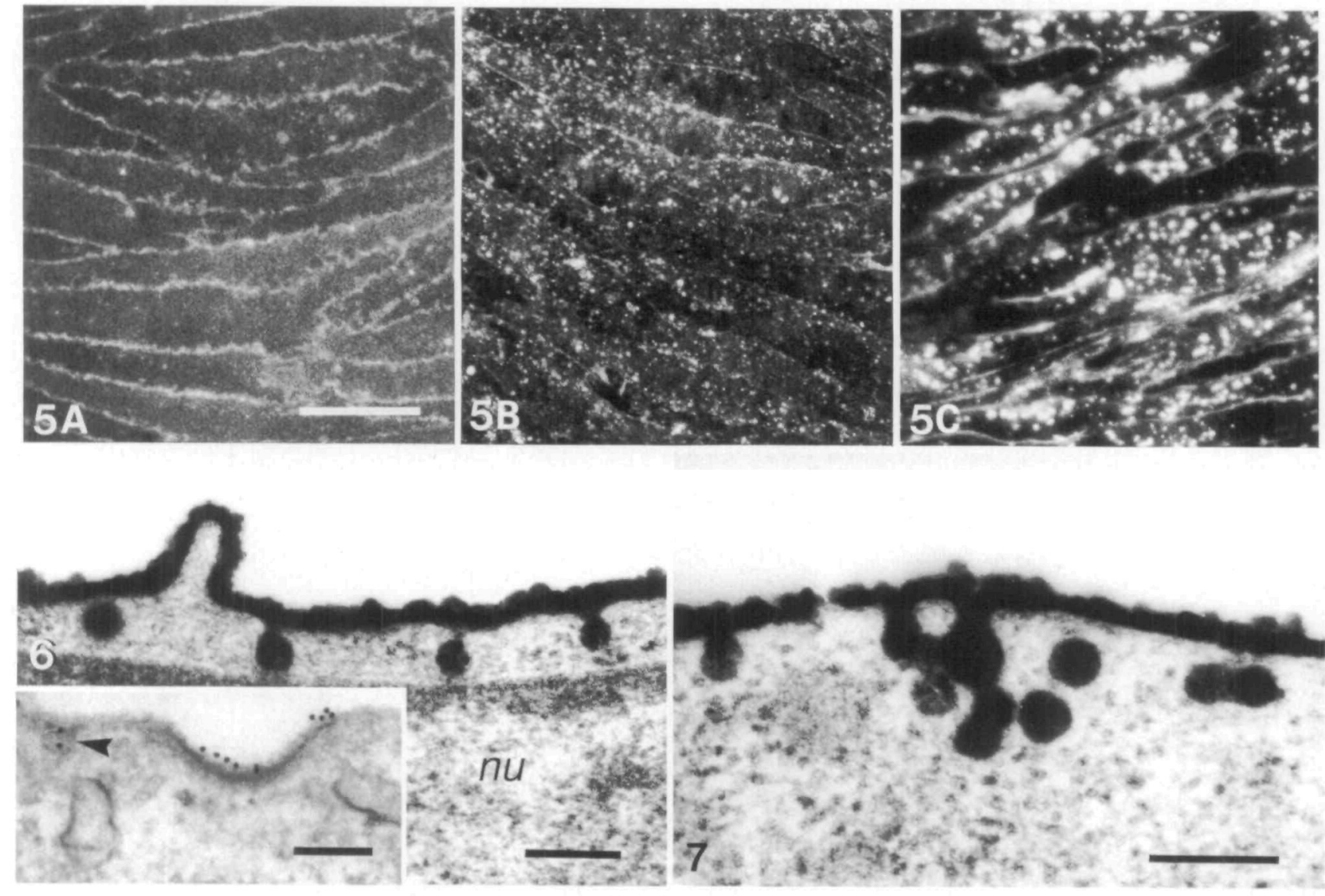

Fig. 5. Binding and internalization of RCAI by confluent BMEC monolayers was examined by fluorescence microscopy. Cells at day 10 in culture were incubated for $30 \mathrm{~min}$ at $4^{\circ} \mathrm{C}$ with $0.2 \mu \mathrm{M}$ FITC-RCAI, rinsed and fixed with paraformaldehyde either immedıately (A) or after warming the labeled cells to $18^{\circ} \mathrm{C}(\mathrm{B})$ and $37^{\circ} \mathrm{C}(\mathrm{C})$. Bar, $20 \mu \mathrm{m}$.

Fig. 6. Distribution of RCA binding sites on BMECs was shown by using cell surface-bound RCAI conjugates and electron microscopy. Confluent BMEC monolayers at day 10 in culture were incubated for 30 min at $4^{\circ} \mathrm{C}$ with $0.2 \mu \mathrm{M} \mathrm{HRP}-\mathrm{RCAI}$ or $0.05 \mu \mathrm{M}$ gold-RCAI (inset) and processed immediately for cTEM as described in the text. RCAI binding sites were distributed evenly over the entire apical plasma membrane including within caveolae (1-2\% of the surface; see Fig. 8), nu, nucleus. Bar, $200 \mathrm{~nm}$. Inset: RCA binding sites also were localized within an occasional clathrin-coated pit and in micropinocytic invaginations (arrowhead). Bar, $100 \mathrm{~nm}$.

Fig. 7. Ultrastructural distribution of BMEC surface RCA binding sites following endocytosis. Within 2.5 min after returning cells that had bound HRP-RCAI to $37^{\circ} \mathrm{C}$, numerous invaginations and putative vesicles that contained lectin were formed and often appeared to be racemose. Cells that had bound HRP-RCAI as in Fig. 6 were rinsed, warmed in serum-free medium, and processed for cTEM. Bar, $200 \mathrm{~nm}$. 
at $4{ }^{\circ} \mathrm{C}$ were found within smooth-membraned invaginations or caveolae that were $70-75 \mathrm{~nm}$ in diameter (Figs 6, 7, 9,11). Although a few coated pits were observed to contain RCAI at $4^{\circ} \mathrm{C}$ (Fig. 6), these regions were not thought to be involved significantly in endocytosis, since so few invaginated coated pits relative to caveolae were found. Using gold-RCAI, we quantified the specific binding of the lectin as a function of density. There were $17 \pm 8$ gold particles $\mu \mathrm{m}^{-1}$ plasma membrane after $20 \mathrm{~min}$ at $4^{\circ} \mathrm{C}$. Control cells that had been labeled in the presence of $0.1 \mathrm{M}$ galactose had only $1.7 \pm 0.2$ gold particles $\mu \mathrm{m}^{-1}$ plasma membrane. Furthermore, labeled cells that were held at $4^{\circ} \mathrm{C}$ for an additional $60 \mathrm{~min}$ had $9 \pm 3$ gold particles $\mu \mathrm{m}^{-1}$ plasma membrane.

Immediately after warming to $37^{\circ} \mathrm{C}$, the number of labeled caveolae and vesicles at the cell surface increased and were closely associated (Fig. 7). Although these clusters appeared to be interconnected, further attempts to show this unequivocally were not pursued. Fig. 8 shows the quantitative change in distribution of gold-RCAI during endocytosis. These results were consistent with the kinetics obtained using $\left[{ }^{125} I\right] R C A I$ (see Fig. 4). GoldRCAI was lost rapidly from the cell surface and appeared first in caveolae and cytoplasmic vesicles. By $5 \mathrm{~min}$, as much as $43 \%$ of the label at the plasma membrane was associated with the stomata or the vesicular 'body' of the caveolae (see Figs 6,11) compared to only $1-2 \%$ prior to endocytosis (Fig. 8). Afterwards, the portion of gold particles in caveolae and vesicles declined and was followed by a gradual increase within endosomes (Fig. 8).

As early as $5 \mathrm{~min}$ after warming the labeled cells to $37^{\circ} \mathrm{C}$, RCAI became lacalized within tubules $(45 \mathrm{~nm}$ diameter) and endosomes (200-400 nm diameter) that were irregular in shape and surrounded by vesicles and tubules (Figs 8-9). The RCAI conjugate within the endosomal lumen was distributed unevenly in association with intraluminal membranes (Fig. 9). The density of gold-RCAI particles per $\mu \mathrm{m}$ of endosomal membrane increased as much as sixfold by $15 \mathrm{~min}$, when an apparent steady state was reached. As endocytosis continued, RCAI conjugate appeared within numerous vesicles and tubules (55-90 $\mathrm{nm}$ in diameter) located trans-most to the Golgi apparatus between 15 and $30 \mathrm{~min}$ (Fig. 10). This distribution contrasted with that of HRP alone, which visualized the fluid-phase endocytic pathway. HRP accumulated within small vesicles of $70 \mathrm{~nm}$ in diameter as early as $10 \mathrm{~min}$ at $37^{\circ} \mathrm{C}$ and within endosomes by $30 \mathrm{~min}$; however, at no time was HRP detected within the trans-Golgi compartments (results not shown).

Less than $0.1 \%$ or 1 in 1000 gold particles of the gold-RCAI was found on the basolateral side of the BMEC monolayer after $60 \mathrm{~min}$ at $37^{\circ} \mathrm{C}$ (Fig. 11). Vesicles that contained lectin conjugate were observed infrequently to be continuous with the basolateral surface (Fig. 11B) or with the lateral membrane at regions lacking the microfilament-associated plaque (results not shown). The density of gold-RCAI that remained at the apical surface had decreased $90 \%$ (Fig. 8 ) by $60 \mathrm{~min}$ at $37^{\circ} \mathrm{C}$ and all was located exclusively within caveolae (Fig. 11).

Recycling of RCAI from a non-degradative compartment Return of internalized RCAI to the cell surface was examined by allowing cells to accumulate [ $\left.{ }^{125} \mathrm{I}\right] \mathrm{RCAI}$ to equilibrium (e.g. $60 \mathrm{~min}$ ), removing the cell surface-associated lectin at $4^{\circ} \mathrm{C}$ with galactose and re-warming the cells to $37^{\circ} \mathrm{C}$ with and without galactose present in the medium (Fig. 12). In the presence of galactose, RCAI that returned

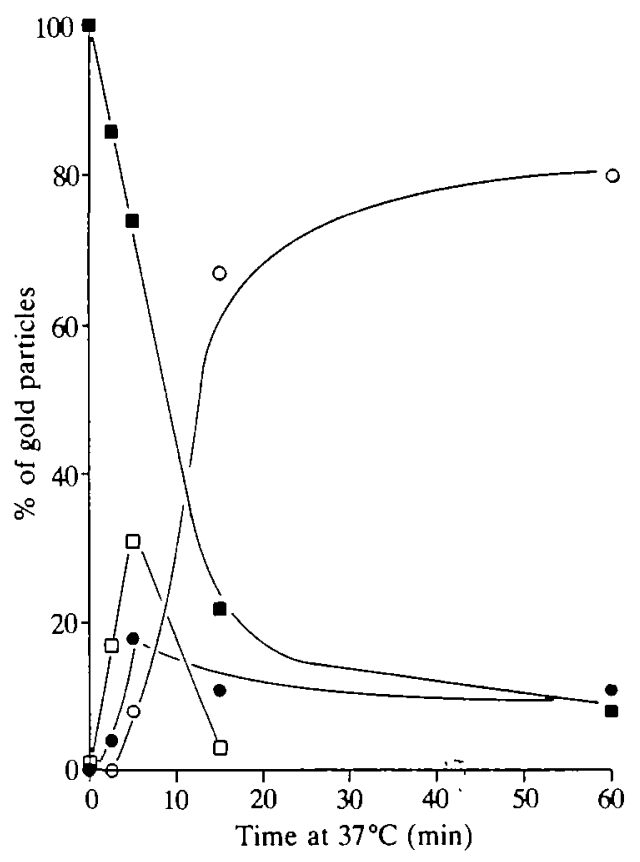

Fig. 8. Kinetics of endocytosis from quantitative morphometry of gold-RCAI distribution. Cells were labeled with gold-RCAI as described for Fig. 6 and either processed immediately $(0 \mathrm{~min})$ or warmed to $37^{\circ} \mathrm{C}$ in serum-free medium for up to 60 min prior to processing for cTEM. More than 300 gold particles were counted for each time point from at least 10 electron micrographs at constant magnification. The location of each gold particle was assigned to plasma membrane $(\mathbf{\square})$, caveolae $(\square)$, vesicles $(\bigcirc)$ or endosomes $(O)$, and the results were plotted as a fraction of the total number of gold particles counted.

to the cell surface was removed and, therefore, was unavailable for another round of recycling. In the absence of galactose, this RCAI was re-internalized. By $1 \mathrm{~h}$ at $37^{\circ} \mathrm{C}$ $60 \%$ of the intracellular radioactivity was returned gradually to the cell surface in the presence of galactose, $15 \%$ in the absence of galactose and $5 \%$ in the presence of galactose but at $4^{\circ} \mathrm{C}$. In all cases, the radioactivity that appeared within the medium was intact protein. Pseudofirst-order kinetics gave efflux a $t_{\mathrm{s}}$ of $13.5 \mathrm{~min}$. Using bovine adrenal endothelia, slightly more of the intracellular RCAI was recycled with a twofold increase in rate $\left(t_{1}=7.5\right)$ of efflux (Fig. 12). These results were specific to galactose, since only $24( \pm 2) \%$ and $18( \pm 1) \%$ of the RCAI was returned in the presence of equimolar concentrations of glucose and mannose, respectively (results not shown).

We next asked whether the intracellular pool of recycling RCAI was constant or if a portion was temporally removed to a slowly or non-recycling compartment. We simply varied the length of time allowed for internalization of cell surface-bound $\left[{ }^{125} \mathrm{I}\right] \mathrm{RCAI}$ with the idea that more of the RCAI might enter a latent compartment at the longer times. The rate and extent of efflux was unaffected after accumulation for up to $60 \mathrm{~min}$ (results not shown).

\section{Discussion}

In recent years, many studies have focused on receptormediated endocytosis and transcytosis by endothelia, yet membrane traffic and the extent of recycling remain largely unknown (Davies, 1984; Simionescu, 1988). In this 

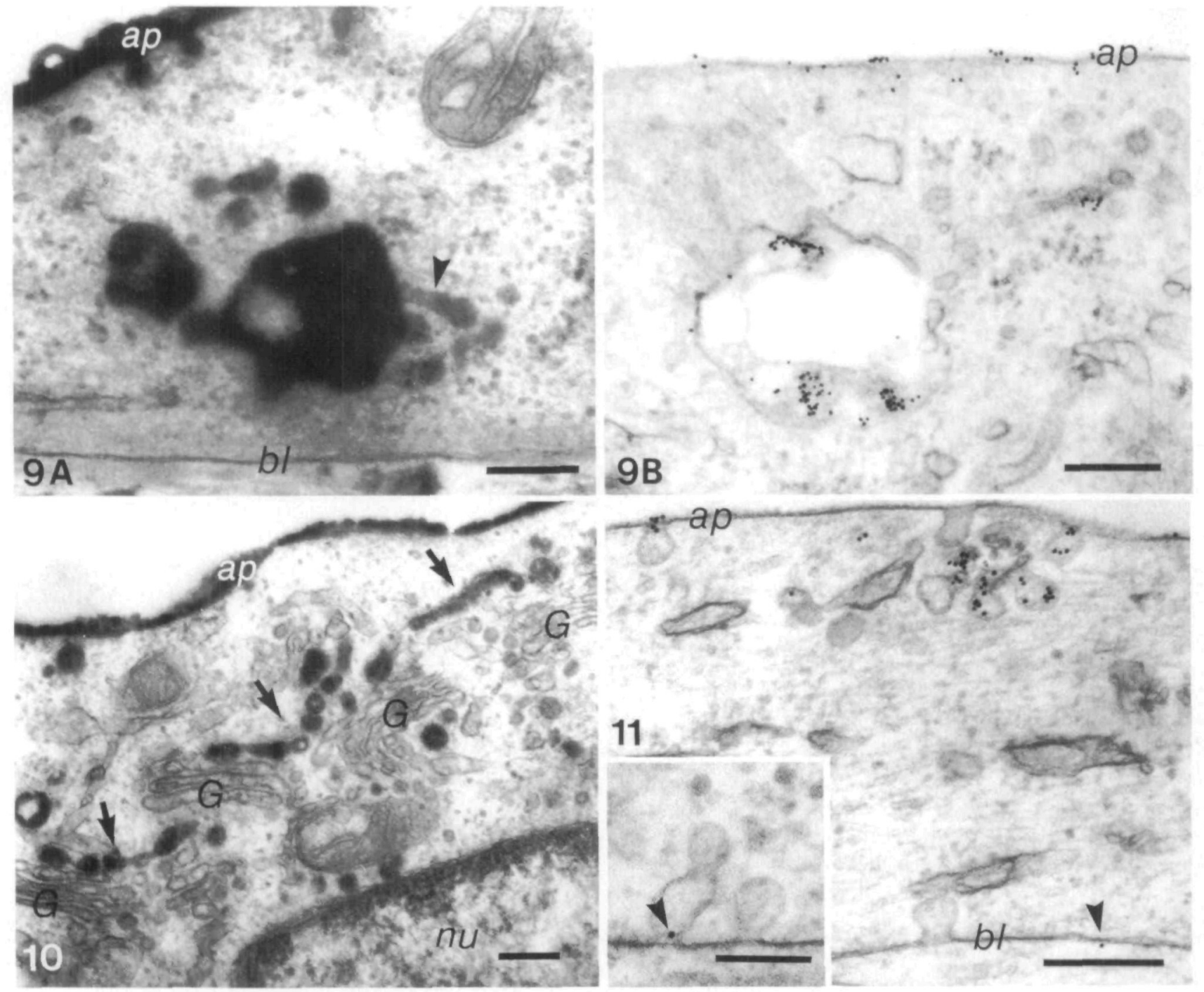

Fig. 9. Ultrastructural distribution of BMEC surface RCA binding sites following endocytosis. Endosomes, vesicles and associated tubules (arrowhead) accumulated RCAI after warming pulse-labeled cells to $37^{\circ} \mathrm{C}$ for $15 \mathrm{~min}$. Confluent cell monolayers were treated with either HRP-RCAI (A) or gold-RCAI (B) as described for Fig. 6, rinsed, and warmed in serum-free medium prior to processing for cTEM. Some label remained on the apical membrane (ap) and was absent from the basolateral membrane (bl). Bars, $200 \mathrm{~nm}$.

Fig. 10. Ultrastructural distribution of BMEC surface RCA binding sites following endocytosis. Within 30 min of warming cells to $37^{\circ} \mathrm{C}$ as for Fig. 9, a fraction of the apical membrane (ap) bound HRP-RCAI was routed to the trans-Golgi network (arrows). Lectin was not localized within the Golgi (G) cisternae per se. Bar, $200 \mathrm{~nm}$.

Fig. 11. Ultrastructural distribution of BMEC surface RCA binding sites following endocytosis. After $60 \mathrm{~min}$ at $37^{\circ} \mathrm{C}$, most of the apical membrane (ap)-bound gold-RCAI was still associated with caveolae or endosomes (not shown). Only an occasional gold particle (arrowheads) was found on the basolateral membrane (bl) and sometimes was associated with a membrane invagination (inset). This suggested that a very small fraction of the apical membrane RCA binding sites entered a transcytotic route. Inset: bar, $100 \mathrm{~nm}$. Bar, $200 \mathrm{~nm}$.

study, we examined the kinetics of membrane recycling in cultured brain endothelia by measuring the accumulation and efflux of the lectin RCAI. This lectin was chosen because it appeared to have the most binding sites of the lectins tested. We showed that RCAI bound to a subpopulation of cell surface glycoproteins and/or glycoplipids of which the majority cycled between the plasma membrane and several intracellular compartments. At least a portion of these cycling glycoproteins were routed through the trans-Golgi network (TGN) (Griffiths and Simons, 1986).

Our results from the survey of lectin binding to cultured BMECs were consistent with the results of others both in vitro and in vivo. Brain MEC of mouse, rat, canine, bovine, and human stained intensely with RCAI (Nag, 1985;
Vorbrodt et al. 1986; Gerhardt et al. 1986; Fatehi et al. 1987; Debbage et al. 1988). Also, except for human BMECs (Debbage et al. 1988), BMECs of all species were UEAI negative. Also, SBA bound equally as well as RCAI however, binding apparently is species dependent. While rat $\mathrm{BMECs}$ were strongly positive for SBA (Nag, 1985), canine BMECs were weakly positive (Fatehi et al. 1987) and human BMECs were negative (Debbage et al. 1988). Together, these results suggested that primary cultures of BMECs have a surface composition that is similar to that found in vivo.

Expression of the RCAI binding proteins was stable throughout culture with only minor changes. We observed some changes in the RCAI binding proteins of BMECs that 


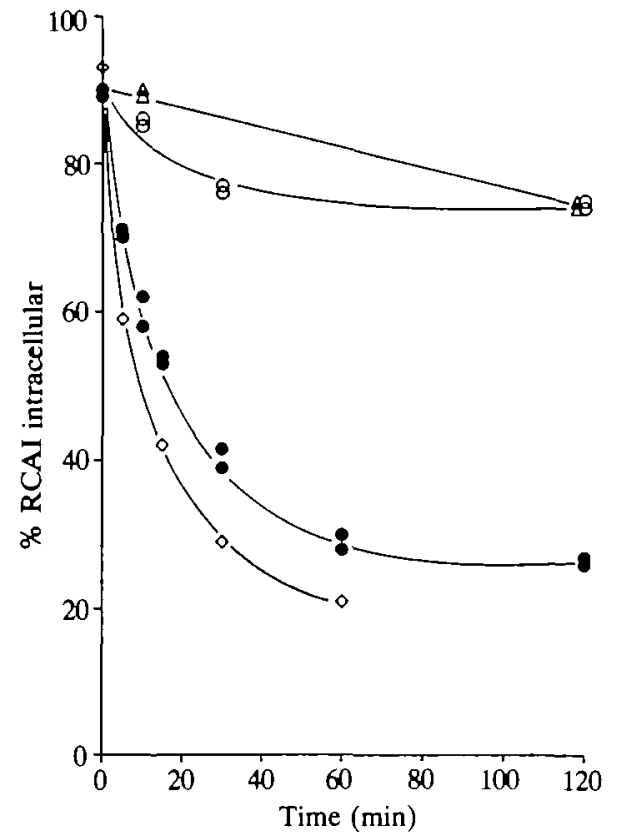

Fig. 12. Efflux of intracellular RCA binding sites from BMEC monolayers $(\odot, \bigcirc, \Delta)$ and from bovine adrenal endothelia $(\diamond)$. Cells that had bound $\left[{ }^{125} \mathrm{~T}\right] \mathrm{RCAI}$ at $4^{\circ} \mathrm{C}$ as for Fig. 3 were allowed to endocytose for $30 \mathrm{~min}$ at $37^{\circ} \mathrm{C}$. After removal of the remaining surface-bound lectin with ice-cold galactose, the cells were either maintained at $4^{\circ} \mathrm{C}(\Delta)$ or returned to $37^{\circ} \mathrm{C}$ in serum-free medium alone $(O)$ or containing $0.05 \mathrm{~m}$ galactose $(0, \bigcirc)$. At selected times, cells were chilled and treated with galactose, rinsed and solubilized. The intracellular radioactivity was plotted as a fraction of the surface-bound label that was endocytosed. Each data point is the mean of triplicate wells. Standard deviations (not shown) were $<5 \%$ of the mean.

had been passaged several times in culture. Fatehi et al. (1987) also showed that both SBA and DBA binding sites were lost in passaged cells. The avidity of RCAI is not restricted to $\mathrm{BMECs}$, but is a universal feature of most endothelia examined (Simionescu, 1988). Moreover, the caveolar membrane has a high density of galactosyl-rich glycoproteins (Simionescu et al. 1982). Since these surface invaginations are most likely involved in endocytosis, this was another reason we chose RCAI as a probe for membrane traffic.

Accumulation and efflux of RCAI were energy-dependent events and were inhibited by low temperature or by metabolic poisons. We showed previously that the majority of fluid accumulation by cultured BMECs was not energydependent and that this was consistent with the results of others for endothelia in vitro (Guillot et al. 1990). Brain MECs have a very low capacity for fluid accumulation and the kinetics of uptake suggest that the majority of cellassociated fluid is within a single compartment of small size that is near to the plasma membrane (Guillot et al. 1990). This study could not determine if this compartment was continuous with the plasma membrane or was continually and rapidly detaching and fusing with it. The results in the present study showed that BMECs have a greater capacity to accumulate membrane-adsorbed molecules than solutes. The kinetics of accumulation and efflux for both fluid and membrane recycling were very different, with the latter being much slower. Together, these results suggested that the bulk flow of membrane is designed to minimize contact with blood components, i.e. a short-circuit pathway for fluids, and maximize interaction with specific blood components for subsequent routing through the membrane pathway for self-utilization or for transcytosis. Such a scenario is paramount to barrier function.

These results most likely were not the result of lectin toxicity, e.g. inhibition of protein synthesis, since cell viability was not affected at the lectin concentrations and for the duration of the incubations used here. Moreover, pure RCAI has almost no toxicity like that attributed to ricin toxin (Olsnes et al. 1974). We have not ruled out unequivocally, however, that RCAI binding and subsequent internalization were influenced by the lectin itself. For instance, concanavalin A was shown to induce internalization in macrophages (Edelson and Cohn, 1974), but at concentrations greater than $30 \mu \mathrm{g} \mathrm{ml}^{-1}$. We know that high concentrations of RCAI $\left(10 \mu \mathrm{g} \mathrm{ml}^{-1}\right)$ increased the amount of Lucifer Yellow that was accumulated by BMECs by $58 \%$ after $10 \mathrm{~min}$ (F. Guillot, unpublished results). However, at the concentrations $\left(<0.5 \mu \mathrm{g} \mathrm{ml}^{-1}\right)$ used in these kinetic studies, this effect was minimal. Gonatas et al. (1980) found that concentrations of RCAII $\left(\mathrm{RCA}_{60}\right)$ up to $50 \mu \mathrm{g} \mathrm{m}^{-1}$ did not stimulate or inhibit endocytosis in a neuroblastoma cell line. As a general phenomenon in endothelia, others reported that high concentrations ( $>5 \mathrm{mg} \mathrm{ml}^{-1}$ ) of proteins, which presumably are internalized by an adsorptive process, stimulated fluid-phase endocytosis (Williams et al. 1981, 1984). Although the concentration of albumin used in this study to prevent nonspecific adsorption of RCAI was much less $\left(1 \mathrm{mg} \mathrm{ml}^{-1}\right)$, its influence on endocytosis is unknown. Moreover, an influence of albumin on endocytosis by BMECs was less likely, since these endothelia do not possess albumin receptors (Simionescu et al. 1988; Smith and Borchardt, 1989).

Because RCAI is bivalent (Olsnes et al. 1974), endocytosis may have been induced by cross-linking of cell surface glycoconjugates. Such interactions might have resulted in the routing of the lectin-membrane complexes to compartments not accessed by the recycling membrane alone or in the exclusion of such complexes from the constitutive pathway. For example, cross-linking of the $\mathrm{Fc}$ receptor on macrophage resulted in degradation of the ligand-receptor complex within lysosomes (Mellman and Plutner, 1984). Our data showed that only a small quantity of internalized RCA was degraded after prolonged incubation, suggesting that RCA-membrane complexes bypassed the lysosome. This was not surprising, since we showed previously that cultured BMECs have few lysosomes as defined by the localization of acid phosphatase (Baranczyk-Kuzma et al. 1989). Another explanation is that RCAI was delivered to lysosomes and either was recycled rapidly through this compartment or was resistant to degradation (Olsnes, 1978; Sandvig and Olsnes, 1978). Our morphological results were consistent with the absence of lysosomal involvement, since HRP-RCAI did not label large, spherical compartments. In contrast, free HRP accumulated within compartments with diameters greater than $500 \mathrm{~nm}$. We expected HRP to be routed to lysosomes if it was truly a nonabsorbed marker in these cells (Steinman and Cohn, 1972). Free HRP does not gain access to the TGN compartment (Gonatas et al. 1984; van Deurs et al. 1987; Raub et al. 1990a). Cell fractionation studies are needed to define the involvement of lysosomes in the endocytic pathway of BMECs.

By using the rate constants calculated from the pseudofirst-order rates of binding, internalization and efflux, we 
estimated a mèan transit time $\left(t_{\mathrm{c}}=\left(k_{1}\right)^{-1}+\left(k_{2}\right)^{-1}+\left(k_{x}\right)^{-1}\right.$; Owensby et al. 1989) of $48 \mathrm{~min}$ for cycling of the RCAIbinding sites. At least $80 \%$ of the binding sites were involved. This value may actually be an underestimate, since we could not determine if the remaining $20 \%$ was actually sequestered or just not stripped efficiently by the method employed. Kinetically, there was no evidence for the temporal movement of a fraction of this cycling pool into a second compartment. We also observed this using a fluid-phase marker (Guillot et al. 1990). These results were not consistent with results in non-endothelial cells showing that a second compartment exists from which membrane-bound ligands are slowly recycled (Mellman et al. 1984; Raub et al. 1986; Raub et al. 1990b). Therefore, most if not all of the cycling RCAI binding sites in BMECs appeared to be routed through one kinetically defined compartment.

Our comparison to passaged bovine adrenal endothelial cells suggested that RCAI efflux was faster and more extensive than in BMECs; however, how that relates to the specialized function of BMECs is uncertain. Similar studies with unpolarized Chinese hamster ovary cells using WGA gave a mean transit time of 35 min (Raub et al. $1990 b$ ). Studies of this kind have not been done with other endothelia, so direct comparisons are impossible. However, kinetic studies using specific ligand-receptor complexes have been done. For example, efflux of insulin from rat epididymal fat endothelial cells had a $t_{1}$ of $18 \mathrm{~min}$ (Bottaro et al. 1989) and is similar to that reported here for efflux of RCAI. Efflux of insulin from isolated brain capillaries had a $t_{i}$ of $70 \mathrm{~min}$ (Pardridge et al. 1985) although most was not energy-dependent and may reflect diffusion from an extracellular space. Efflux of transferrin, which recycles through the TGN (Stoorvogel et al. 1988), from isolated rat epididymal fat capillaries was very rapid with $80 \%$ logt within $20 \mathrm{~min}$ (Wagner et al. 1983). We also measured transferrin efflux from BMECs in primary culture and found a $t_{1}$ of $38 \mathrm{~min}$ (Raub and Newton, 1990), which is much longer than that in epididymal fat capillaries and shown here for RCAI binding sites. The significance of these differences is unclear, since the effects of isolation procedures and culture conditions on these events are unknown.

We assumed in this study that the RCAI conjugates behaved like native and iodinated RCAI; however, this may not be true for the gold-RCAI. Because it is a polyvalent probe, i.e. many molecules of RCAI per gold particle, subsequent intracellular routing may be altered as discussed above. For instance, while native ${ }^{125} \mathrm{I}$ labeled) and gold-ricin toxin behaved with similar kinetics during endocytosis (van Deurs et al. 1985) the gold-ricin toxin was excluded from the TGN (van Deurs et al. 1986). In contrast, the HRP-ricin toxin conjugate was not excluded due presumably to its monovalence (Gonatas et al. 1984; van Deurs et al. 1986). Our morphological results suggested a similar discrepancy between goldRCAI and HRP-RCAI. Very little of the gold-RCAI compared to HRP-RCAI was localized within the TGN of BMECs. On the other hand, our morphometric quantitation of gold-RCAI distribution during uptake gave kinetics that were reminiscent of data obtained using $\left[{ }^{125}\right.$ I]RCAI. This suggested that inaccessibility of goldRCAI to the TGN had little effect on the kinetics of cycling of most of the RCA-binding site population. This could be interpreted as indicating that the fraction of RCAI binding sites that was routed to the TGN was small. We did not, however, measure efflux of the gold-RCAI conjugate.
Our data showed that a fraction of the RCAI binding sites was routed through the TGN of BMECs. Broadwell et al. (1988) also reported the involvement of Golgi-associated compartments in BMECs in vivo following endocytosis of HRP-wheat germ agglutinin (WGA) from the apical or blood-side surface. The appearance of HRPWGA within this compartment took considerably longer $(>3 \mathrm{~h})$ than reported here $(>30 \mathrm{~min})$ for HRP-RCAI and may reflect differences between cultured cells and those in situ or between the respective populations of binding sites. Transcytosis of HRP-WGA to the basolateral surface of BMECs in vivo was observed after $6 \mathrm{~h}$ (Broadwell et al. 1988). We found that only a very small fraction of RCAI conjugates crossed the BMEC monolayer after $2 \mathrm{~h}$ although more might be transcytosed with longer incubations.

Although the physiological significance of the transcytotic pathway as seen with lectins is unknown, our results indicated that $\mathrm{BMECs}$ in primary culture are polarized. Along with the presence of tight junctions that physically define the apical and basolateral membrane domains (Dragsten et al. 1981), BMECs are capable of maintaining functional polarity, despite the fact that RCAI binding sites are present equally on both membrane domains (Vorbrodt et al. 1986). We also provided evidence that BMECs maintain a polarized fluid recycling pathway in primary culture (Raub and Newton, 1990). In vivo, the apical surface of BMECs is almost exclusively involved in endocytosis as shown following intraventricular administration of HRP (Broadwell et al. 1983). Brandli and Simons (1989) recently demonstrated polarized recycling of a subset of galactosylated apical membrane glycoproteins through the TGN of Madin Darby canine kidney epithelial cells. Together, these studies suggest that a mechanism exists for selective endocytosis and sorting to the TGN.

The movement of plasma membrane proteins through the TGN is well documented in many cell types and it is known that this pathway involves only a subset of the total recycling population (Reichner et al. 1988; Stoorvogel et al. 1988; van Deurs et al. 1988; Brandli and Simons, 1989). van Deurs et al. (1988) using quantitative immunocytochemistry estimated that $5 \%$ of internalized ricin toxin is in the Golgi region and of that 70-80\% is in the TGN. It was proposed that one route for transcytosis in BMECs might involve the TGN (Broadwell et al. 1988). Sorting of apical proteins to the TGN and subsequent entrance into a basolaterally directed, exocytotic pathway could be the mechanism. Such a pathway, albeit a minor one, may explain how cationized proteins, which are nonspecifically adsorbed to the cell surface, are transcy. tosed in BMECs (Kumagai et al. 1987; Triguero et al. 1989; Smith and Borchardt, 1989). Indeed, Stoorvogel et al. (1988) showed in hepatoma cells that the endocytic and secretory pathways are connected in the TGN.

In conclusion, we have measured the endocytosis and recycling of RCAI binding sites within primary cultures of BMEC monolayers. The majority of internalized binding sites were recycled, relatively slowly compared to a fluidphase marker (Guillot et al. 1990), from what appeared to be a single kinetic compartment. In other words, the data suggested that a second, nonrecycling or more slowly recycling compartment was not involved. Morphologically, the endocytic pathway encountered by these internalized RCAI binding sites involved caveolae, peripheral endosomes and smooth-membraned tubules, and vesicles of which a portion was located in the TGN. Moreover, these internalized RCAI binding sites were not routed to the 
basolateral membrane domain under the conditions employed, suggesting that the endocytic membrane pathway is polarized in vitro as has been shown in vivo (Broadwell et al. 1988).

We thank Dr Gospodarowicz for supplying us with the passaged cultures of bovine brain and adrenal microvessel endothelia. We also thank Dr Roger Ulrich for use of the Electron Microscopy facility at The Upjohn Company, Mr Ken Kilgore for technical assistance in the microscopy, and Ms Brenda Mussulman for preparing the manuscript.

\section{References}

Audus, K. L. AND BorchardT, R. T. (1986) Characterization of an in vitro blood-brain barrier model system for studying drug transport and metabolism. Pharm. Res. 3, 81-87.

AUdU日, K. L. AND BorchanDT, R. T. (1987). Bovine brain microvessel endothelial cell monolayers as a model system for blood-brain barrier. Ann. N. Y. Acad. Scl. B07, 9-18

Baranczyk-Kuzma, A., Auduz, K. L. and Borchardt, R. T. (1986). Catecholamine-metabolizing enzymes of bovine brain microvesse endothelial cell monolayers. $J$. Neurochem. 46, 1956-1960

BapanczYs-KuzMa, A. RAuB, T. J. AND Audus, K. L. (1989). Demonstration of acid hydrolase activity in primary cultures of bovine brain microvessel endothelium. J. cereb. Bl. Fl. and Metab. 9, 1-10.

BotTaro, D. P., Bonner-Wrir, S. AND King, G. L. (1989). Ingulin receptor recycling in vascular endothelial celle. J. bool Chem. 284 5916-5923.

Bowman, P. D., Ennis, S. R, Rarhy, K. E., Bhtz, A. L. and Golngthin, G. W. (1983). Brain microvessel endothelial cells in tisaue culture: a model for study of blood-brain barrier permeability. Ann. Neurol. 14, $396-402$

Brandl, A. W. AND Simons, K. (1989). A restricted set of apical proteins recycle through the trans-Golgi network in MDCK cells. EMBO J. 8, 3207-3213.

BriohtmaN, M. W. (1989). The anatomic basis of the blood-brain barrier. In Implications of the Blood-Brain Barrier and its Manipulation, vol. 1 (ed. E. A. Neuwelt), pp. 53-83. New York, London' Plenum Press.

Broadwell, R. D., Batin, B. J. and Salcman, M. (1988). Trangeytotic pathway for blood-borne protein through the blood-brain barrier. Proc. natn. Acad. Sci. U.S.A. 85, 632-636.

Broadwrll, R. D., Balin, B. J., Salcman, M. and Kaplan, R. S. (1983). Brain-blood barrier? Yes and no. Prac. natn Acad. Scl. US.A. 80, $7352-7356$

Careon, M. P. and Haudengchild, C. C. (1986). Microvagcular endothelium and pericytes: high yield, low passage cultures. In Vutro 22, 344-354.

DAvise, P F. (1984). Quantitative aspects of endocytosis in cultured endothelial cells. In Biology of Endothelial Cells (ed. E. A. Jaffe), pp. 365-376. Boston, The Hague: Martinus Nijhoff Publishers.

Debiagr, P. L., Gabius, H.J., Bish, K. and Marguth, F. (1988), Cellular glycoconjugates and their potential endogenous receptors in the cerebral microvasculature of man: a glycohistochemical study. Eur. J. Cell Biol. 46, 425-434.

Dragsten, P. R., Blumethal, R. and Handler, J. S. (1981). Membrane symmetry in epithelia: is the tight junction a barner to diffusion in the plasma membrane. Nature 204, 718-722.

DunN, W. A., Hubbare, A. L. ANd Aronson, N. N. Jr (1980). Low temperature selectively inhibits fusion between pinocytic vesicles and lysosomes during heterophagy of ${ }^{125} \mathrm{I}$-asialofetuin by the perfused rat liver. J. biol Chem. 255, 5971-5978.

Edrlson, P. J. AND COHN, Z. A. (1974). Effects of concanavalin A on mouse peritoneal macrophages. I. stimulation of endocytic activity and inhibition of phago-lysosome formation. J. exp. Med. 140, 1364-1386.

Fatehi, M. I., Gerhardt, D. Z., MYerg, T. G. AND Drewer, L. R. (1987). Characterization of the blood-brain barrier: glycoconjugate receptors of 14 lectins in canine brain, cultured endothelial cells, and blotted membrane proteins. Brain Res, 415, 30-39.

GrRHARDT, D. Z , Zlonis, M. S. AND Drewes, L. R. (1986). Light and electron microscopic localization of D-galactosyl residues in capillary endothelial cells of the canine cerebral cortex. $J$ Histochem. Cytochem. 34, 641-648.

Goldstein, G. W., Betz, A. L. and Bowman, P. D. (1984) Use of isolated brain capillaries and cultured endothelial cells to study the bloodbrain barrier. Fedn Proc. Fedn Am. Socs exp. Biol. 43, 191-195.

Gonatas, J., Stibeer, A., Olsner, S. and Gonatas, N. K. (1980). Pathways involved in fluid phase and adsorptive endocytosis in neuroblastoma. J. Cell Biol. 87, 579-588
Gonatas, N. K. Stirber A., Hickgy, W. F., Herbert, S. H. and Gonatas, J. O. (1984) Endosomes and golgi vesicles an adsorptive and flud phase endocytosis. J. Cell Biol. 99, 1379-1390.

Gospodarowicz, D., Massoglia, S. AND ChENG, J. (1986). Effect of fibroblast growth factor and lipoproteins on the proliferation of endothelial celle derived from bovine adrenal cortex, brain cortex, and corpus luteum capillaries. J. cell. Physiol. 127, 475-484.

Grufriths, G. AND Simons, K. (1986). The trang Golgi network: sorting at the exit site of the Golgi complex. Science 294, 438-443.

Gullot, F. L., Audus, K. L. and Raud, T. J. (1990). Fluid-phase endocytosis by primary cultures of bovine brain microvessel endothelial cell monolayers. Mucrouasc. Res. 39, 1-14.

HuBBard, A. L. AND COHN, Z. A. (1975). Externally disposed plasma membrane proteins. I. Enzymatıc iodination of mouse L cells. J. Cel Biol. 64, 438-460.

Kumagai, A. K., Elgengerg, J. B. and Pardridge, W. M. (1987). Absorptive-mediated endocytosis of cationized albumin and a B. endorphin-cationized albumin chimenc peptide by isolated brain capillaries. J. biol. Chem. 262, 16 214-15 219

LARMMLI, U. K. (1970) Cleavage of structural proteins during the assembly of the head of bacteriophage T4. Nature 227, 680-685.

LUFT, J M. (1961). Improvements in epoxy resin embedding methods. $J$. biophys. blochem. Cytol. $\mathbf{9}, 409$

MARKWEl, M. A. K., HaA8, S. M., Tolbert, N. E. AND Bigeer, L. L. (1981). Protein determination in membrane and lipoprotein samples: manual and automated procedures. Meth. Enzym. 72, 296-303.

MrLliman, I. AND PlUTNER, H. (1984). Internalization and degradation of macrophage $\mathrm{Fc}$ receptors bound to polyvalent immune complexes. $J$. Cell Biol. 98, 1170-1177.

Mrliman, I , Plutiner, H. and Ukronen, P (1984). Internalization and rapid recycling of macrophage $F c$ receptors tagged with monovalent antireceptor antibody: possible role of a prelysosomal compartment. $J$ Cell Biol. 98, 1163-1169.

NAG, S. (1985). Ultrastructural localization of monosaccharide residues on cerebral endothelium. Lab. Invest. 52, 553-558.

OusNes, S. (1978). Ricin and ricinus agglutinin, toxic lectins from castor bean. Meth. Enxym. 50, 330-335.

Olsnes, S., Saltvedt, E. ANd Pthl, A. (1974). Igolation and comparizon of galactose-binding lectins from Abrus precatorius and Ricinus communis $J$ biol. Chem. 249, 803-810.

OwrnsBy, D. A., Morton, P. A. AND Schwartz, A. L. (1989), Quantitative evaluation of receptor-mediated endocytosis. In Methods in Cell Biology, vol. 32 (ed. A. M. Tartakoff), pp 305-328. New York: Academic Press.

PARDRIDGE, W. M. (1988). Recent advances in blood-brain barrier transport. A. Rev. Pharmac. Toxicol 28, 25-39.

Pardridge, W. M., Eirgnberg, J. AND YaNG, J. (1986). Human bloodbrain barrier insulin receptor. J. Neurochem. 44, 1771-1778.

Raub, T. J., Denny, J. B. and Roentri, R. M. (1986). Cell surface glycoproteins of CHO cells. I. Internalization and rapid recycling. Expl Cell Res. 165, 73-91.

Raub, T. J., Koroly, M. J. ANd Roberts, R. M. (1990a). Endocytosis of wheat germ agglutinin binding sites from the cell surface into a tubular endosomal network. J. cell. Physiol. 143, 1-12.

RALB, T. J., Koroly, M. J. AND Roberts, R. M. (1990b). Endocytosis and recycling of wheat germ agglutinin binding sites on CHO cells: Evidence for two compartments in a nondegradative pathway. J. cell Physiol. (in press)

RaUb, T. J. AND Newton, C. R. (1990). Membrane recycling, adsorptive and receptor-mediated endocytosis by primary bovine cerebral microvessel endothelial cell monolayers in vitro. In Pharmaceutical Applications of Cell and Tissue Cultures (ed. G. Wilson, S. S. Davis, and L. Illum) (in press). New York, London: Plenum Press.

ReERE, T. S. AND KarNovsky, M. J. (1967), Fine structural localization of a blood-brain barrier to exogenous peroxidase. J. Cell Biol. 34 207-217

Reichner, J. S., Whitrheart, S. W. and Hakt, G. W. (1988). Intracellular trafficking of cell surface sialoglycoconjugates. J. biol. Chem. 263, 16316-16326.

RkYNOLDs, E. S. (1963). The use of lead citrate at high $\mathrm{pH}$ as an electron opaque stain in electron micrascopy. J. Cell Biol. 17, 208-212.

SANDVIG, K. AND OLSNEB, S. (1979). Effect of temperature on the uptake, excretion and degradation of abrin and ricin by HeLa cells. Expl Cell Res. 121, 15-25.

Simionescu, M. (1988). Receptor-mediated transcytosis of plasma molecules by vascular endothelium. In Endothelial Cell Biology in Health and Disease (ed. N. Simionescu and M. Simionescu), pp. 69-104. New York, London: Plenum Prese.

Simionescu, M., Ghinea, N., Fixman, A., Lasser, M., Kukes, L. Sumionescu, N. and Palade, G. E. (1988). The cerebral microvagculature of the rat: structure and luminal surface propertie during early development. J. submicrosc. Cytol. Path. 20, 243-261. Simionescu, M., Simionescu, N. and Palade, G. E. (1982). 
Differentiated microdomains on the luminal surface of capillary endothelium: distribution of lectin receptors. J. Cell Biol. 94, 406-413. Smith, K. R. and Borchardt, R. T. (1989). Permeability and mechanism of albumin, cationized albumin, and glycosylated albumin transcellular transport across monolayers of cultured bovine brain capillary endothelial cells. Pharm. Res. 6, 466-473.

Steinman, R. M. And CoHn, Z. A. (1972). The interaction of soluble horseradish peroxidase with mouse peritoneal macrophages in vitro. $J$. Cell Biol. 55, 186-204.

Stoorvogel, W., Geuze, H. J., Griftrth, J. M. and Strous, G. J. (1988) The pathways of endocytosed transferrin and secretory protein are connected in the trans-Golgi reticulum. J. Cell Biol. 108, 1821-1829.

Triguero, D. Buciak, J. B., Yano, J. and Pardridge, W. M. (1989). Blood-brain barrier transport of cationized immunoglobulin G: Enhanced delivery compared to native protein. Proc. natn. Acad. Scr. U.S.A. 86, 4761-4765.

van Deurs, B., Pedergon, L. R., Sundan, A., Olsnes, S. and Sandvig, K. (1985). Receptor-mediated endocytosis of a ricin-colloidal gold conjugate in vero cells. Expl Cell Res. 169, 287-304.

van Drurs, B., Petergon, O. W., Olanes, S. and Sandvio, K. (1987).

Delivery of internalızed ricin from endosomes to cisternal Golgi elements is a discontinuous, temperature-sensitive process. Expl Cell Res. 171, 137-152.

van Deurs, B., Sandvig, K., Petereen, O. W., Olange, S., Simons, K.
AND Grifriths, G. (1988). Estimation of the amount of intermalized ricin that reaches the trans-Golgi network. J. Cell Biol 106, 253-267. van Deurs, B., Tonnegsen, T. I., Petrerson, O. W., Sandvig, K and OLSNES, S. (1986). Routing of internalized ricin and ricin conjugates to the Golgi complex. J. Cell Biol. 102, 37-47.

Vorbrodt, A. W., Dobrogowska, D. H., Lossingky, A. S. AND Wisnie wski, H. M. (1986). Ultrastructural localization of lectin receptors on the luminal and abluminal aspects of brain micro-blood vessels. J. Histochem. Cytochem. 34, 251-261.

Wagnr r, R. C., Robinson, C. S., Cross, P. J. and Drvenny, J. J. (1983) Endocytosis and exocytosis of transferrin by isolated capillary endothelium Microvasc Res. 25, 387-396

Williams, S. K., Devenny, J. J. And Bitensky, M. W (1981) Micropinocytic ingestion of glycosylated albumin by 18olated microvessels: possible role in pathogenesis of diabetic microangiopathy. Proc. natn. Acad. Sct. U.S A. 78, 2393-2397.

Williams, S. K., Greener, D. A. AND Solengri, N. J. (1984). Endocytogis and exacytosia of protein in capillary endothelium. J. cell. Physiol. 120 , $157-162$

(Received 9 March 1990 - Accepted 17 Aprl 1990) 